\title{
Peranan Iklan Bahaya Merokok dalam Media Sosial pada Era 4.0 di Indonesia
}

\author{
Checi Arum Septiani, Muhammad Ali Sodik \\ Institut Ilmu Kesehatan STRADA Indonesia \\ arumcheci@gmail.com, alisodik2012@gmail.com
}

\begin{abstract}
Abstrak
Tingginya prevalensi merokok di Indonesia harus segera ditangani. Hal ini telah menjadi permasalahan berbagai kalangan, bahkan baik perempuan maupun laki-laki. Adanya media promosi kesehatan sangan cocok sebagai wadah sarana edukasi bahaya merokok. Apalagi saat ini Indonesia dalam era 4.0 dimana semua aktivitas bebasis internet dan teknologi. Tujuan dari artikel ini agar para editor, tenaga medis, creator di luar sana menyebarkan hal baik mengenai kesehatan khususnya kasus merokok ini. Semakin banyak media yang memberikan informasi, semakin banyak juga informasi yang didapat dan akan menyadarkan kita akan hal buruk tersebut. Dengan begitu kita telah menyelamatkan nyawa orang hanya karna rokok.
\end{abstract}

\section{Latar Belakang}

Berdasarkan data The Tobacco Atlas pada 2011, di Indonesia lebih dari 2.677.000 anak dan 53.767.000 orang dewasa mengonsumsi tembakau setiap hari. Indonesia berada di peringkat ketiga sebagai negara dengan jumlah perokok paling tinggi. Prevalensi penduduk Indonesia merokok pada tahun 2021 mencapai 33,8 persen atau sekitar 65,7 juta penduduk. Oleh karena itu, kampanye mengenai bahaya rokok harus terus digalakkan untuk mencegah makin bertambahnya perokok pemula terutama dari kalangan remaja. Iklan mengenai bahaya merokok perlu di tayangkan dalam berbagai media sosial. Pada era 4.0 ini semua kalangan baik tua sampai muda telah menggunakan gadget, sehingga penayangan iklan mengenai bahaya merokok sangat cocok. Pada era 4.0 jika hanya melalui poster atau media cetak lainnya, kuramg rasanya. Perlu 
adanya penayangan video iklan bahaya merokok. Penayangan ini berguna untuk menekan angka prevalensi perokok di Indonesia.

\section{Kasus / Masalah}

Tembakau dapat merugikan kesehatan, perbendaharaan, dan semangat bangsa Indonesia. Setiap tahun, lebih dari 225.700 penduduknya meninggal karena penyakit yang disebabkan oleh tembakau. Namun, lebih dari 469.000 anak (10-14 tahun) dan 64.027.000 orang dewasa (15+ tahun) terus menggunakan tembakau setiap hari. Hampir $80 \%$ perokok di Indonesia mulai merokok ketika usianya belum mencapai 19 tahun.

Melihat kasus yang semakin serius tersebut, berbagai upaya telah dilakukan untuk menekan angka prevalesnsi perokok di Indonesia. Namun, upaya yang telah dikeluarkan tidak membuat perokok jera, justru terjadi penambahan kasus perokok setiap tahunnya. Saat ini, tidak sedikit kita temui remaja perempuan juga mendapati kasus merokok. Sebagai calon tenaga kesehatan saya sangat sedih melihat hal tersebut. perlu adanya langkah serius untuk menghadapi hal ini.

\section{Tinjauan Pustaka}

a. Media Promosi Kesehatan Media promosi kesehatan adalah semua sarana atau upaya untuk menampilkan pesan atau informasi yang ingin disampaikan oleh komunikator, baik melalui media cetak, elektronika (berupa radio, TV, komputer dan sebagainya) dan media luar ruang, sehingga sasaran dapat meningkatkan pengetahuannya yang kemudian diharapkan menjadi perubahan pada perilaku ke arah positif di bidang kesehatan (Notoatmodjo, 2005).

Pengertian yang dirumuskan WHO, Indonesia merumuskan pengertian promosi kesehatan adalah upaya untuk meningkatkan kemampuan masyarakat melalui pembelajaran dari, oleh, untuk dan bersama masyarakat agar mereka dapat menolong dirinya sendiri 
(mandiri)

serta

mengembangkan kegiatan

bersumber daya masyarakat

sesuai sosial budaya setempat

dan didukung oleh kebijakan

publik yang berwawasana

kesehatan.

Pelaksanaan program

promosi kesehatan tidak dapat terlepas dari media promosi kesehatan. Melalui media promosi, maka pesan-pesan kesehatan yang akan disampaikan dapat lebih menarik dan mudah dipahami, sehingga sasaran dapat mempelajari pesan tersebut sehingga sampai memutuskan untuk mengadopsi perilaku yang positifnya. Pentingnya pemilihan media dalam melakukan promosi kesehatan sangatlah diperlukan dengan maksud mempermudah penerimaan sasaran terhadap materi promosi kesehatan yang diberikan (Ardian, 2014:3).

b. Promosi Kesehatan Menggunakan Media Sosial

Media sosial melalui internet memiliki potensi besar untuk melakukan promosi kesehatan dan intervensi kesehatan lainnya, dan lebih mudah untuk menyentuh sasaran pada setiap levelnya. Kurang maksimalnya pemanfaatan media sosial oleh pihak kesehatan yang professional karena terbatasnya kemampuan dalam mengelola informasi kesehatan berbasis media sosial.

Informasi kesehatan yang diperoleh melalui web dengan cepat dan mudah bisa menyebabkan

ketidakseimbangan informasi, karena semua pihak dapat memasukkan informasi walaupun tidak memiliki kompetensi dibidang kesehatan. Hal ini tentu saja berpotensi bahaya akibat kelebihan konsumsi informasi. Masyarakat juga harus diberi informasi tentang informasi yang tesedia apakah layak untuk mereka telusuri. 
Minimnya interaktif antara pencari informasi dengan profesional kesehatan sehingga masyarakat tidak tertarik untuk mengunjungi situs tersebut yang mengakibatkan ketidakberlanjutan program promosi kesehata di media sosial.

c. Merokok

Perilaku merokok adalah aktivitas menghisap atau menghirup asap rokok dengan menggunakan pipa atau rokok yang dilakukan secara menetap dan terbentuk melalui empat tahap, yaitu: tahap preparation, initiation, becoming a smoker, dan maintenance of smoking (Maman, 2009).

$$
\text { Merokok merupakan }
$$

salah satu masalah yang sulit di pecahkan. Apalagi sudah menjadi masalah nasional, dan bahkan internasional. Hal ini menjadi sulit karena berkaitan dengan banyak faktor yang saling memicu, sehingga seolah-olah sudah menjadi lingkaran setan. Di tinjau dari segi kesehatan, merokok harus di hentikan karena menyebabkan kanker di penyumbatan pembuluh darah yang mengakibatkan kematian.

Merokok adalah suatu kebiasaan menghisap rokok yang dilakukan dalam kehidupan sehari-hari, merupakan suatu kebutuhan yang tidak bisa dihindari bagi orang yang mengalami kecenderungan terhadap rokok. Rokok merupakan salah satu bahan adiktif artinya dapat menimbulkan ketergantungan bagi pemakainya. Sifat adiktif rokok berasal dari nikotin yang dikandungnya. Setelah seseorang menghirup asap rokok, dalam 7 detik nikotin akan mencapai otak (Soetjiningsih, 2010). Kegiatan merokok ini tidak bisa dipungkiri lagi sudah mengakar dalam kehidupan masyarakat Indonesia, menjadi budaya dan tradisi masyarakat. Setiap orang memiliki hak untuk memilih apa saja yang ingin dia lakukan, termasuk untuk merokok, adalah hak setiap individu untuk memutuskan apakah dia akan 
merokok atau tidak. Terlepas dari itu, alangkah baiknya jika seorang perokok tau apa dampak dari sebuah keputusan yang mereka ambil itu.

d. Media sosial dalam era 4.0

Perkembangan teknologi komunikasi dan informasi yang begitu cepat saat ini tidak bisa dicegah. Komunikasi melalui media sosial menjadi salah satu contoh nyata. Media sosial sekarang ini seperti pisau bermata dua. Bisa memberi dampak positif dan negatif. Era industri 4.0 memiliki karakteristik kombinasi antara perangkat internet dengan kinerja manusia atau cyberphysical system ternyata memberikan banyak strategi komunikasi hubungan masyarakat untuk dikembangkan.

Pada era 4.0 masyarakat sehat dan pasien lebih mengandalkan Internet daripada dokter sebagai sumber informasi perawatan kesehatan. Situs web media sosial yang populer terbukti efektif dan ampuh untuk menyebarluaskan informasi kesehatan, mendukung upaya promosi kesehatan dan dapat ditelusuri secara online seperti YouTube, Facebook, Instagram, Twitter, dan Tik tok. Lebih dari 100 juta video dilihat di Youtube setiap hari, dan jumlah itu terus meningkat.

\section{Pembahasan}

Merokok bukanlah hal asing untuk masyarakat Indonesia saat ini. Faktanya, banyak orang yang terkena penyakit karena rokok. Berbagai kalangan bahkan anak- anak pun sudah mengenal rokok. Pada kalangan remaja, merokok juga bukanlah hal asing bagi perempuan. Hal ini disebabkan banyaknya faktor pendukung untuk merokok. Padahal, banyak zat berbahaya dalam rokok yang bisa menyebabkan hingga kematian. Namun, hal tersebut sudah tidak dihiraukan lagi untuk para perokok. Sebenarnya dampak merokok tidak hanya untuk para perokok, namun perokok pasif pun juga bisa terkena dampaknya. Perlu adanya edukasi dan media 
pengembangan promosi kesehatan mengenai bahaya merokok.

$$
\text { Indonesia berada pada }
$$
peringkat tertinggi penduduknya sebagai perokok. Setiap tahunnya kasus merokok bertambah. Tidak hanya itu, kasus kematian akibat rokok juga bertambah. Berbagai upaya telah dilakukan tenaga kesehatan maupun pemerintah, tetapi hal tersebut kurang mempengaruhi masyarakat.

Saat ini, Indonesia berada pada era 4.0 sehingga cocok untuk mengembangkan media promosi kesehatan melalui media sosial. Kita melihat bahwa dampak media sosial sangat besar bagi kegiatan sehari hari. Membuat poster, iklan, atau postingan mengenai bahaya merokok perlu ditambahkan lagi. Banyak orang yang tak bisa lepas beraktivitas dengan gadget. Menampilkan semacam iklan perlu sekali untuk dilakukan. Hal ini untuk menyadarkan para perokok yang telah kecanduan tersebut. Dengan bantuan teknologi desain visual yang canggih, hal ini daoat kita manfaatkan untuk dapat menekan angka prevalensi merokok.

\section{Kesimpulan}

Media sosial sangat berdampak bagi kehidupan manusia pada saat ini. Mengingat saat ini Indonesia berada di era 4.0 dimana semua aktivitas berdasarkan teknologi dan internet. Tingginya prevalensi merokok di Indonesia, harus segera diatasi. Apalagi saat ini kasus merokok terjadi di semua kalangan dan jenis kelamin. Aktifnya media sosial bisa kita lakukan sebagai strategi awal memberikan edukasi mengenai bahaya merokok. Sebaiknya, kita juga membuat video iklan mengenai bahaya merokok atau video pendek yang kemudian di upload di media sosial. Dengan tambahan teknologi desain visual yang canggih, akan memperbagus keindahan desain tampilan tersebut. Sehingga ketika orang melihat iklan atau video tersebut akan tertarik. 


\section{Daftar Pustaka}

Sodik, M. A. (2018). Merokok \& Bahayanya.

Jatmika, S. E. D., Jatmika, S. E. D., Maulana, M., KM, S., \& Maulana, M. (2019). PENGEMBANGAN MEDIA PROMOSI KESEHATAN.

Hutabarat, E. N. N., \& Indrayani, M. (2021). PENGARUH KARAKTERISTIK DAN PERSEPSI INDIVIDU TENTANG PERINGATAN BAHAYA MEROKOK PADA BUNGKUS ROKOK TERHADAP PERUBAHAN SIKAP PEROKOK AKTIF DILINGKUNGAN XXVII KELURAHAN PEKAN LABUHAN KECAMATAN MEDAN LABUHAN. Jurnal Maternitas Kebidanan, 6(1), 66-79.

Yulius, Y. (2016). Peranan desain komunikasi visual sebagai pendukung media promosi kesehatan. Besaung: Jurnal Seni Desain dan Budaya, 1(2).

Leonita, E., \& Jalinus, N. (2018). Peran Media Sosial dalam Upaya Promosi Kesehatan: Tinjauan Literatur. INVOTEK: Jurnal Inovasi Vokasional dan Teknologi, $18(2), 25-34$.

Septiani, C. A. (2021). Penyakit Yang Ditimbulkan Oleh Rokok.

Soetjiningsih. (2010). Tumbuh Kembang Remaja dan Permasalahannya. Jakarta: Sagung Seto. 